DOI: $10.35355 / 0000057$

\title{
O AGON SISTÊMICO DA ANTIGUIDADE
}

\author{
Julio Aurelio Vianna Lopes* \\ Fundação Casa Rui Barbosa \\ julio64aurelio@gmail.com
}

RESUMO: O artigo aplica a teoria integracionista de Marcel Mauss (1872/1950) para compreender as civilizações antigas como configurações institucionais assumidas pela generalização da dádiva agonística - exercício competitivo da obrigação de retribuir - cujo predomínio caracteriza o respectivo período histórico.

PALAVRAS-CHAVE: dádiva agonística - civilizações antigas - servidão

\section{THE AGON SYSTEMIST OF ANTIQUITY}

\begin{abstract}
The article applies the integrationist theory from Marcel Mauss (1872/1950) to understand ancient civilizations as institutional configurations by spreading the agonistic gift - a competitive exercise of retribution obligation - whose predominance characterizes the respective historical period.
\end{abstract}

KEYWORDS: agonistic gift - ancient civilizations - servitude

Mas essa prestação adquire, da parte do chefe, um caráter agonístico muito marcado. Ela é essencialmente usurária e suntuária, e assiste-se antes de tudo a uma luta dos nobres para assegurar entre eles uma hierarquia (...)

Marcel Mauss -Ensaio sobre a dádiva

Pesquisador Titular em Ciências Sociais e Humanas da Fundação Casa de Rui Barbosa. Doutor em Ciência Política pelo Instituto Universitário de Pesquisas do Rio de Janeiro. Pós-Doutor em Sociologia pela Universidade Federal de Pernambuco. Membro da Cátedra UNESCO de política cultural e gestão. 
Disponível em: www.revistafenix.pro.br

À caracterização específica e unitária da Antiguidade - abrangendo Ocidente e Oriente antigos - também pode contribuir a teoria integracionista do etnólogo Marcel Mauss (1872/1950), especialmente suas formulações sobre trocas mediante dádivas e suas respectivas obrigações sucessivas de dar, receber e retribuir bens (MAUSS, 2003, pp. 243/251). Este intelectual sempre apelou a cientistas sociais pelo recurso à disciplina científica da História (MAUSS, 2015, pp. 16/18/99/100), à medida que, progressivamente, se afastava do viés positivista de seu tio Emile Durkheim, ao tomar o grau de integração social (e não sua morfologia) como principal parâmetro comparativo geral entre sociedades, inclusive, no tempo (MAUSS, 2017, pp. 65-70).

Para uma abordagem integracionista da Antiguidade como período histórico, se pode destacar o conceito maussiano de dádiva agonística: pelo qual definiu qualquer interação social em que a retribuição de bens (materiais ou não) é competitiva e exponencialmente crescente, implicando trocas (econômicas ou não) nas quais se retribua sempre e cada vez mais do que se recebe (MAUSS, 2003, pp. 249/250). O próprio Mauss encontrara o fenômeno amplamente delineado entre os trácios do norte grego (especialmente odrises) como “(...) dádivas com recuperação usurária (...)" (MAUSS, 2015, p. 357) e em alguns aspectos jurídicos e econômicos de antigos romanos, indianos, chineses e germânicos (MAUSS, 2003, pp. 265 -293).

No viés maussiano, a integração social é tendência - embora não inexorável contínua: grupos tendem a se formar, ampliar e suas eventuais desintegrações integram processos de agrupamento mais abrangentes. Sociedades difusamente integradas e com poder central extrínseco às mesmas - típicas das primeiras civilizações (MAUSS, 2017, pp. 68-70) - implicariam instituições erigidas sobre coletividades primordiais e para veicularem trocas competitivas entre dádivas na e/ou à população.

O integracionismo maussiano distingue duas formas de troca entre dádivas:

- A dádiva-partilha (GODBOUT, 1998), na qual se trocam bens materiais ou não - para cessar ou evitar rivalidades, convertendo estranhos em familiares mediante comunhão coletiva: "Neles tudo se mistura, tudo o que constitui a vida propriamente social das sociedades que precederam as nossas (...)" (MAUSS, 2003, p. 187);

- A dádiva agonística, na qual se trocam bens - materiais ou não - para rivalizar com seus donatários ou com outros doadores, estando “(...) mais ligados ao dispêndio e à exatidão em retribuir usurariamente as 
Disponível em: www.revistafenix.pro.br

dádivas aceitas, de modo a transformar em obrigados aqueles que os obrigaram.” (MAUSS, 2003, p. 238)

Neste sentido, a hipótese que almejo corroborar é a de que a generalização hegemônica desta forma (agonística) de troca entre dádivas caracteriza a Antiguidade histórica. Embora sua ocorrência, obviamente e segundo o próprio Mauss, seja ordinária em qualquer sociedade - inclusive modernas, nas quais “(...) assim rivalizamos em nossos brindes de fim de ano, em nossos festins, bodas, em nossos simples convites para jantar e sentimo-nos ainda obrigados a nos revanchieren, como dizem os alemães" (MAUSS, 2003, p. 193) - pretendo demonstrar que foi na Antiguidade que o agon maussiano (MAUSS, 2003, p. 192) se sistematizou e que tal sistematização caracteriza especificamente este período histórico, moldando as instituições antigas pela dinâmica agonística de competir para retribuir ou generosidade competitiva.

A intensificação agonística da troca entre dádivas - principalmente da obrigação de retribuição superior ao recebido - caracterizou as civilizações antigas, nas quais sua predominância informava institucionalidades redistributivas em Estados Tributários (WOLFE, 1994). Nelas, se pode constatar tanto o espraiamento de dádivas competitivas em modalidades diversas de servidão (permeando a sociedade inteira, da família ao trabalho e à ordem politica), quanto a sua configuração governamental pelas variadas formas agonísticas que a dádiva assumiu, em cada qual. Revisitando estas civilizações - sob o paradigma maussiano da dádiva e ${ }^{1}$ - poderemos verificar, assim, como a troca agonística de dádivas (que tornava exponenciais as retribuições devidas) acarretou tanto o formato tributário e redistributivo de bens por suas elites, quanto disseminou a servidão como relação social, em geral.

De fato, a configuração assumida pela dádiva agonística propiciou, em cada civilização antiga, a institucionalização de formas especificas de servidão, implicando, assim, que a variedade institucional entre civilizações antigas também decorreu da modalidade assumida pela onipresente e predominante competição para retribuição que orientava suas populações e elites. Assim, passo a expor como a trajetória - gênese e evolução - de cada civilização antiga exprime como o exercício competitivo de dádivas (agonísticas) emergiu e permeou tais sociedades, tornando-se sistêmico nelas, as quais:

${ }^{1}$ Cf.: (CAILlÉ, 1998) e (GODBOUT, 1998) 
Disponível em: www.revistafenix.pro.br

- Advém da superação de comunhões coletivas entre grupos - cujas trocas de dádivas importa partilha sem rivalidade relevante (MAUSS, 2003, p. 187) - pela disseminação social de dádivas agonísticas;

- Se institucionalizaram segundo a forma e a extensão assumida, especificamente - em cada civilização antiga - pelo exercício de dádivas agonísticas tão específicas quanto generalizadas.

As quatro civilizações ${ }^{2}$ expostas - como sistemas de dádivas agonísticas - a seguir, na impossibilidade de abranger o espectro de Estados Tributários - foram cases escolhidos por sua duração milenar (Egito Faraônico), por remanescerem na atualidade (Índia e China) ou ser matriz ocidental (Império Romano).

\section{CIVILIZAÇÃO EGIPCIA}

No Egito faraônico, da unificação à conquista macedônica (3000 a 332 antes da Era Comum), houve uma sociedade rigidamente estratificada entre grupos de pat, henmemet e rehyt (CARDOSO, 1987, p. 20). Os primeiros eram patrícios aristocráticos, descendentes de pioneiros da agricultura propiciada ao longo do rio Nilo e fundamental ao sedentarismo adotado pela população egípcia. Os segundos (povo solar) compunham uma nobreza menor de círculos próximos aos pat e os terceiros eram as pessoas comuns, completando uma escala de privilégios decrescentes e concomitantes à crescente dependência pessoal (CARDOSO, 1987, p. 20).

Como no suposto maussiano, também há indícios de dádiva-partilha (MAUSS, 2003, p. 187) - comunhões coletivas sem rivalidade relevante - através de organizações comunitárias aldeãs, cuja composição de anciões (ur) remanesceu durante o terceiro e parte do segundo milênio antes da Era Comum. Embora progressivamente submetidas, pois seus chefes eram responsabilizados pelo governo nos casos de não pagamento de tributos pelas aldeias, provavelmente advinham de assembleias arcaicas. Tais controles não extirparam a dimensão comunitária dessas organizações, de modo que permaneciam

\footnotetext{
2 Emprego o termo segundo a conotação dada por Mauss (em texto de 1929): "Um fenômeno de civilização é (...) um fenômeno difundido numa massa de populações mais vasta do que a tribo, do que a horda, do que o pequeno reino, do que a confederação das tribos. (...) Ademais, do mesmo modo como todos os outros fenômenos sociais, eles têm um fundo no passado, na História." (MAUSS, 2015, p. 479)
} 
"conselhos de irrigação" locais, ainda que submetidos à burocracia estatal (MORET, 1937, pp. 313/323 /555).

A competição de dádivas agonísticas, entre sacerdotes (prestações divinas) e guerreiros (proteções militares contra saqueadores), à população, caracteriza a trajetória desta civilização, desde sua emergência imemorial: institucionalizados, respectivamente, nos inumeráveis templos e nas dinastias faraônicas, estes grupos disputavam o mesmo prestígio social (e religioso). Era nesta disputa de dádivas à população que se calcava a captação e redistribuição dos excedentes produzidos no País, como relações diretas com unidades de produção agropecuária. À competição por prestigio se mesclava, assim, a luta pela hegemonia do sistema redistributivo e, portanto, também pela alocação de servos por ambas as instituições.

O pêndulo, geralmente instável entre faraós e templos - apesar das raras confrontações, como a tentativa do faraó Akhenaton de institucionalizar Aton (Sol) como única divindade - se inclinou, desde o início do primeiro milênio antes da Era Comum, para os templos, quando se emanciparam de ingerências governamentais (CARDOSO, 1987, p. 19). Então, “decretos de isenção", pelos faraós, das corveias reais (trabalhos compulsórios fixados para determinadas datas ou obras públicas), isentaram, progressivamente, os sacerdotes, bens e trabalhadores que serviam aos templos, inclusive em suas terras (CARDOSO, 1987, p. 20).

A dinâmica tributária predominou no Egito Antigo, correspondente às dadivas agonísticas entre faraós e templos, os quais, para tanto, concentraram e modelaram a subserviência da população - inclusive como centros de redistribuição econômica. Funcionários, artesãos e artistas dos círculos dinásticos e sacerdotais se beneficiavam de sua inserção institucional e, como proprietários, dispunham (não só por concessões ou doações de superiores) de servos que lhes eram agregados, assim como os que serviam aos sacerdotes e aos governantes. Pode-se supor que a disputa crônica, entre templos e faraós, favoreceu as tantas variedades de servidão egípcia, quanto os direitos dos servos (CARDOSO, 1987, p. 21).

A corveia real era o tributo mais importante, para viabilizar obras faraônicas, especialmente para defesa militar e irrigação agrícola. Implicava, frequentemente, a formação provisória de povoados compulsórios, dos quais os convocados - que não se limitavam aos estratos inferiores - não poderiam se evadir e moravam sob uma estrita vigilância policial. A evasão acarretava escravidão hereditária (imputada a si e seus 
Disponível em: www.revistafenix.pro.br

descendentes) ao Estado, o qual deles dispunha até para eventuais doações a particulares. Tal penalidade alcançava também egípcios que cometessem crimes graves e se permitia a venda de si mesmo como escravo (CARDOSO, 1987, pp. 23/25/27).

Dentre as formas de trabalho compulsório (KLOSTERBOER, 1960, p. 02), a escravidão era excepcional no Egito faraônico, pois a servidão não consistia, comumente, na propriedade do trabalhador - intrínseca ao escravo (DAVIS, 1968). A escravização provinha de processos extemporâneos, como os citados (aos quais se acrescentavam estrangeiros aprisionados em guerras, frequentemente doados pelo rei aos soldados), devido à abundância de agregados servis nos meios dinásticos e templários. Seus estabelecimentos de trabalho, no Estado e nos templos, eram carcerários (shenau), mas isto não ocorria a escravos domésticos e a todos evidenciando que a escravatura não era paradigmática da servidão egípcia - era facultado adquirir propriedade, se casar com não escravos (os filhos seguiam o status da mãe) ou ser adotados e até testemunhar contra seus donos: tinham personalidade jurídica (CARDOSO,1987, p. 28).

\section{CIVILIZAÇÃO INDIANA}

Povoada, no mínimo, há 5.000 anos, por grandes aldeias que fixavam clãs em torno de campos agrícolas e de rebanhos, a Índia da Idade do Bronze chegara a constituir cidades - já encontradas mais de 80 por arqueólogos ${ }^{3}$. Sua organização (cultura dasa), entre 2.500 e 1.500 antes da Era Comum, apresentava indícios da dadiva-partilha: celeiros coletivos para estoque de cereais empregados como moedas (gerais) de troca e, na maior cidadela, um complexo público de compartimentos à volta de uma piscina, a qual tem sido considerada um tanque de purificação condizente com o tradicional (e atual) costume indiano de banho purificador nos tanques de templos ou na água sagrada de um rio. ${ }^{4}$

A colonização da região pelos aryas (nômades pastoris), entre 1.500 e 1.200 antes da era comum, impôs sua presença aos dasas e se iniciou um amálgama progressivo de culturas (AUBOYER, 1957). Mauss, que considerava o Direito Hindu

3 Conferir o primeiro capítulo de A civilização Indiana (ANEQUIN, 1979).

4 Conferir o primeiro capítulo de A civilização Indiana (ANEQUIN, 1979). 
Disponível em: www.revistafenix.pro.br

Clássico, dentre os que mais conservaram traços da dádiva arcaica (comunhão entre grupos), também via a Índia Antiga, logo após a colonização ariana, como duplamente agonística: nela identificava relações sociais deste tipo tanto nos maiores grupos nativos (Assam e Mundos) quanto nos colonizadores de origem indo-europeia, onde o agon era corrente (MAUSS, 2015, pp. 276- 279).

Pois é na dadiva agonística exercida (como no Egito Antigo) por sacerdotes e guerreiros - grupos arianos de protetores divinos e militares - em face dos demais, que se pode detectar sua tradução no escalonamento indiano de castas (varnas), que caracterizou o País e ainda condiciona todos os seus aspectos. Em sua gênese, ambos os grupos dirigem a população, amealhando privilégios correspondentes, mas não havia, ainda, divisões nítidas fora deles. ${ }^{5}$

Progressivamente, a estratificação alcança o conjunto da população, detalhando “dádivas obrigatórias" como deveres específicos a cada varna, enquanto se acentua a rivalidade agonística entre religiosos (brâmanes) e militares (xatryas). Diferenciam-se as castas - cuja impermeabilidade também não foi imediata - dos vasyas (negociantes em acepção ampla) e dos sudras (subalternos em termos igualmente amplos) ${ }^{6}$. Por exclusão, o sistema aponta os dalits como párias sem inserção social.

Nos estamentos jurídicos das varnas se condensa a dinâmica tributária indiana: os brâmanes, que se dedicam, comumente, aos rituais (suas dádivas próprias), são os oficiantes permanentes da sociedade, pois todo ato relevante da vida privada ou pública é acompanhada do sacrifício, devidamente instruído. ${ }^{7}$ Assumindo tal condição cartorial, os brâmanes se consolidaram no topo hierárquico, pois sempre lhes cabe o ensino dos textos sagrados (Vedas), ao menos metade dos honorários ritualísticos e doações variadas pelas demais castas. Seu sacrifício pessoal inclui as prescrições alimentares e sexuais mais estritas; deles advinha o sacerdote máximo (puroita), nomeado pelo rei. ${ }^{8}$

Aos nobres guerreiros (xatryas), cuja dadiva era a proteção militar da população e foram, geralmente, os grandes proprietários territoriais do País, cabia auferir as rendas de suas propriedades, inclusive in natura. Tendo sidos chefes de clã ou

\footnotetext{
5 Conferir o capítulo dois de $A$ vida cotidiana na Índia Antiga (AUBOYER, 1957)

6 Conferir o capítulo dois de A vida cotidiana na Índia Antiga (AUBOYER, 1957)

7 Conferir o capítulo dois de A vida cotidiana na Índia Antiga (AUBOYER, 1957)

8 Conferir o capítulo dois de A vida cotidiana na Índia Antiga (AUBOYER, 1957)
} 
Disponível em: www.revistafenix.pro.br

tribo, evidenciavam-se por grandes sacrifícios, como o do cavalo (asvameda), e pela entronização solene pelos sacerdotes (partilhando o topo da hierarquia social). Desta casta advinha o rei, por direito hereditário, embora frequentemente ratificado pela população. ${ }^{9}$ Já os vasyas tinham o dever de se dedicar à agropecuária, artesanato e comércio, mas, ainda quando acumulassem fortunas e se organizem em corporações, se sujeitavam, diretamente, aos xatryas, como rendeiros que também os tinham de nutrir e auxiliar nas guerras. ${ }^{10}$

À casta inferior dos sudras - provavelmente formados pelos descendentes dos aborígenes aos quais se impuseram os aryas - era atribuído o dever de servir, como dependente pessoal, às castas acima. Seu contingente (sem acesso ao sacrifício e ao estudo do Veda) era acrescentado pelos condenados por dividas ou cuja pena fora comutada, além, eventualmente, de prisioneiros de guerra. ${ }^{11}$ Aos dalits restou a pior sorte: sua "impureza" é considerada tão intensa (da noção indiana de Karma decorre que cada pessoa nasce com dívidas não saldadas em outras vidas e correspondentes à sua casta) que sua exclusão social continua desafiadora, enquanto aos sudras é facultado o resgate de sua condição, pelo enriquecimento pessoal. ${ }^{12}$

Tal como no Egito Faraônico, a Índia Antiga dispunha de um sistema variado de dependências pessoais - porque proveniente da dádiva agonística entre sacerdotes e guerreiros - e abrangente da população: castas superiores contém subgrupos que tornam o sistema ainda mais complexo, ${ }^{13}$ de modo que a escravidão não foi relevante como forma de servidão. Escravos eram raramente adotados, até mesmo pelos nobres guerreiros que obtinham cativos de guerra.

\section{CIVILIZAÇÃO CHINESA}

Com mais de 5.000 anos de civilização documentados (CHENG, 2000, p. 15), os chineses antigos “(...) aparecem como um povo de agricultores. (...) Na verdade, a terra chinesa revelou sua fecundidade de cantão por cantão e ao preço de trabalhos

\footnotetext{
9 Conferir o capítulo dois de A vida cotidiana na Índia Antiga (AUBOYER, 1957)

10 Conferir o capítulo dois de A vida cotidiana na Índia Antiga (AUBOYER, 1957)

11 Conferir o capítulo dois de A vida cotidiana na Índia Antiga (AUBOYER, 1957)

12 Conferir o capítulo dois de A vida cotidiana na Índia Antiga (AUBOYER, 1957)

13 Conferir o capítulo dois de A vida cotidiana na Índia Antiga (AUBOYER, 1957)
} 
heroicos. (...) Os camponeses conheciam o sacrifício que custam esses primeiros trabalhos. Eles gostavam de cantar os méritos dos ancestrais que haviam desbravado o País" (GRANET, 1979, p.212). Em torno deste sedentarismo milenar, sob constante ameaça (GRANET, 1979, p. 32/33) de nômades das fronteiras (considerados bárbaros), encontramos indícios de uma dádiva - partilha arcaica e de seu gradativo deslocamento por uma dádiva agonística, cuja configuração básica atravessou toda a antiguidade chinesa, incluindo o Império (findo em 1911 da Era Comum).

$\mathrm{Na}$ China arcaica dos cantões (anterior a 2.100 antes da Era Comum), as mulheres (tecelãs) radicavam neles, onde coordenavam um nomadismo complementar (masculino), pelo qual os homens (lavradores) percorriam, ao longo do dia, os campos de cereais (AYMARD,1957 p. 92): uma ordem matriarcal conferida pela ocupação feminina ininterrupta das aldeias, das quais não arredavam e onde as sementes estavam sob a guarda delas - especialmente da anciã mais velha.

Casas masculinas recolhiam os homens, cujas aproximações com as mulheres eram furtivas, devido a interditos durante o período diurno (no qual se desenrola o trabalho), enquanto a divindade que imbuía o solo também era feminina: a Mãe-Terra. Coletivas eram as uniões conjugais, que fundiam famílias em festas aldeãs, onde também ocorriam jogos comunitários e cujo molde se manteve mesmo em organizações camponesas sob domínio feudal, nas quais algum grau de liberdade sexual - inclusive de orgias - se manteve (GRANET, 1979, p. 38 a 41). "Na época da concórdia camponesa e das comunhões igualitárias, a solidariedade das famílias associadas em comunidades rurais era obtida por meio de prestações que eram, ao mesmo tempo, alternadas e totais." (GRANET, 1979, p.215)

A dádiva-partilha aldeã, predominantemente feminina, foi sendo, gradativamente, decomposta pelo exercício de dádivas agonísticas no seio e entre as confrarias masculinas das aldeias, que, durante o inverno (impróprio ao lavradio), reuniam as casas dos homens. Eram festas onde apresentavam habilidades em danças e torneios, respectivamente, de harmonização com divindades da Natureza local e técnicas de cultivo dos alimentos ou de combate a saqueadores. Sob a forma de "justas" masculinas, esboçavam uma hierarquia social pela reverência a heróis locais, que se solidifica em atributos masculinos a divindades agrárias e que se consolida no culto sistemático ao Ancestral heroico pelo seu descendente, que agora dirige os trabalhos agrícolas. Enfeudam-se, assim, os camponeses que se submetem a um Senhor Ancestral, 
de cuja linhagem provém o Senhor (feudal) que pode intermediá-los com a Natureza local e da qual dependem. ${ }^{14}$

Ao Senhor feudal competia, portanto, o estabelecimento do calendário agrícola, devido à sua capacidade (hereditária) de mediação com a Natureza e suas divindades, tal como a do Grande Antepassado, afortunado por elas. Apenas a submissão ao calendário oficial e ao seu autor senhorial, poderia evitar o infortúnio das colheitas insuficientes ou inadequadas. Dele proviria a dádiva da boa colheita (pela Natureza) e da segurança (contra os saques), de modo que o Senhor local concentrava as dádivas religiosas e militares - incluídas nas agrícolas. Daí sua ascendência religiosa (único prestador do culto aos Deuses do solo e ao seu Ancestral) e militar (comandante das guerras) na comunidade. ${ }^{15}$

Neste sentido, cabe reconhecer que uma dádiva agonística caracterizava a relação entre o Senhor e a comunidade, já que a fortuna (boa ou má) da mesma implicava, diretamente, em fortalecimento (fertilidade comunitária) ou enfraquecimento (pela fuga de camponeses) do domínio senhorial (AYMARD,1957, p. 118). Mais que as guerras com os nômades, que rondavam os povoados chineses, as campanhas bélicas sobre outros feudos, constantemente provocadas por bravatas senhoriais (GRANET,1979, p. 197 a 199), alimentava o mandato ancestral e divino de prestigiar o Antepassado Sagrado e a comunidade local, ampliada pela enfeudação (parcial o mais das vezes) de terras ou camponeses do Senhor vencido.

Ao cultuar seu Antepassado, de fato, o Senhor feudal rivalizava com seu prestigio ancestral, com o qual era obrigado a se equiparar, reiteradamente, ao risco de derrocada do domínio atual. Seu agon consistia na competição com as dádivas longínquas do Fundador da comunidade, às quais suas dádivas tinham de se emparelhar. Embora solitárias, suas dádivas eram agonísticas porque o compeliam a um desempenho que definia seu prestigio senhorial. Esta dádiva agonística mandatária, ao tempo que concentrava no Senhor feudal todos os aspectos (econômico, religioso e militar) do domínio, também o precarizava, diante de turbulências internas ou externas principalmente da Natureza, com a qual era o único mediador.

Efetivamente, os mortos (Antepassados Sagrados) dominavam os vivos, através do seu prestigio ancestral, que se reproduzia pela boa fortuna local (agrícola e

\footnotetext{
${ }^{14}$ Conferir os capítulos vinte a vinte e três de A Civilização Chinesa (GRANET, 1979)

${ }^{15}$ Conferir os capítulos vinte a vinte e três de $A$ Civilização Chinesa (GRANET, 1979)
} 
militar) ou dele destituía o Senhor da comunidade desafortunada. A etiqueta feudal chinesa não afetava o Grande Antepassado, pois o templo ancestral era preservado no solo do Senhor vencido em guerra ou derrubado por sublevação. Ele apenas era destituído como indigno do mandato divino de seu Ancestral, procedendo-se à sua substituição por um novo mandatário, ao qual caberia honrar, nos mesmos termos, o prestigio conferido pelo Antepassado: eventual mudança senhorial era sinal suficiente da reinvestidura do mandato pelo próprio Ancestral (GRANET, 1979, capitulo 10 e AYMARD,1957 p. 86 a 88). Doravante, o novo Senhor assumia as dádivas, especialmente da Natureza, à comunidade feudal.

Tal dádiva agonística, rivalizando os prestígios senhorial e ancestral, atravessou todo o período feudal - inclusive as dinastias (Xia, Shang e Zhou) que reuniam confederações de domínios, entre 2.000 e 476 antes da Era Comum - e durante as guerras seculares entre os Reinos Combatentes (475 a 221 antes da Era Comum), quando os maiores domínios se confrontaram pela supremacia militar. Mas também se projetou no período imperial (221 antes da Era Comum a 1911 da Era Comum), quando o Imperador enfrentava, em âmbito nacional, as mesmas vicissitudes de um mandato divino. O monarca era "Filho do Céu", mesmo título conferido ao chefe da coalizão de domínios locais que, durante as primeiras dinastias feudais, conduzia as guerras com os nômades fronteiriços. Tratava-se do mesmo prestigio senhorial, já que, por não exercer domínio local, mas nacional, o Imperador era vassalo do Céu (Natureza ou seu Regente), o qual se sobrepunha às deidades locais. ${ }^{16}$

Do Céu (que o trataria como filho ou principal vassalo) ele exercia um mandato celeste que lhe impunha as mesmas honrarias prestadas pelos senhores feudais, como chefe do culto, através do Altar do Céu (equivalente ao Altar do Solo no feudo) e do calendário. Mediador solitário com a Natureza, o Imperador se arrogava a ordem natural, inclusiva da humana (PALMER, 2005, p. 18 a 21 e 27 a 29). Assim, as dinastias imperiais, malgrado a relevante burocracia estatal que a distinguia dos domínios feudais, reproduziam a dádiva agonística mandatária de tempos pretéritos.

À concentração pessoal das obrigações de proteção (da Natureza e dos estrangeiros), característica da dádiva agonística ancestral, correspondeu a submissão,

16 Conferir os capítulos vinte e sete e vinte e oito A Civilização Chinesa (GRANET, 1979) 
cada vez mais abrangente, da comunidade (local, provincial e nacional). Emergente com o calendário senhorial, a dinâmica tributária chinesa submeteu os camponeses, os círculos aristocráticos crescentes em torno do nobre feudal, as burocracias auxiliares, expandidas em seu proveito e a população de todo o território, à medida que se avançava em direção à centralização imperial. Importa destacar que a servidão chinesa foi um processo evolutivo, de modo que suas crises (como o desmembramento de domínios militares dos Zhou, no período feudal ou as sublevações camponesas, sob algumas dinastias imperiais) sempre foram equacionadas pela reiteração da dinâmica tributária relativa à dádiva agonística ancestral: pela profusão e/ou aperfeiçoamento da regulamentação dos vários aspectos da sociabilidade.

Neste sentido, foi uma dinâmica tributária em constante alargamento comunitário que impeliu a evolução institucional chinesa, condizente com a intensificação continuada do mandato agonístico (cujas eventuais destituições do titular só tornavam maiores a dívida pessoal do novo mandatário). Assim, o domínio senhorial se estabeleceu no âmbito local, se espraiou para o âmbito confederativo e se consolidou na burocracia nacional do Império. Suas crises, mesmo quando redundaram em longas guerras civis, reiteraram a mesma dinâmica, com novos protagonistas:-outros mandatários para o mesmo mandato divino - ancestral (feudal) ou celeste (imperial).

Os lavradores eram rendeiros e acessórios dos bens feudais de raiz, suas festas campestres submetidas ao domínio senhorial - embora mantidas - e suas famílias, ainda que com menos intensidade que as dos nobres, reproduzem a vassalagem ao Grande Ancestral na dependência pessoal (interna) aos ascendentes e ao primogênito. ${ }^{17}$ No meio nobiliárquico, devido à proximidade - inclusive parental - com o Grande Mandatário feudal, e acesso ao culto ancestral, os regulamentos senhoriais são, necessariamente, mais detalhados. Em todos os aspectos, até mesmo para a incorporação da primeira esposa (esposas secundárias eram admitidas, em graus correlatos à nobreza do vassalo) e de qualquer filho, o Antepassado importava, pois eram novos prestadores de seu culto religioso. Uma cidade senhorial, no centro do feudo, abrigava o clã do regente feudal. ${ }^{18}$

O cerimonialismo, entendido como tendência ao detalhamento regulamentar, apenas expandiu seu diapasão, concomitante ao crescimento dos domínios senhoriais,

17 Conferir os capítulos dezoito e dezenove A Civilização Chinesa (GRANET, 1979)

18 Conferir o capítulo vinte e seis A Civilização Chinesa (GRANET, 1979) 
Disponível em: www.revistafenix.pro.br

cuja rivalidade militar levou às guerras entre o fim da dinastia Zhou e a fundação do Império. Com o desenvolvimento da burocracia imperial, a vassalagem permaneceu a matriz das relações como o "Filho do Céu", porém se ampliou o acesso ao círculo senhorial (possível, mas raro no âmbito feudal) de pessoas externas à nobreza: exames de serviço civil são abertos, de modo a incrementar a competição entre servidores do Poder - já encontrada na hierarquia feudal e reproduzida pelo escalonamento imperial das classes nobiliárquicas.${ }^{19}$ Entre os feudos senhoriais, passando pela ascensão e queda dos domínios guerreiros, permeando as dinastias imperiais, a dinâmica tributária evoluiu, reiterando-se durante suas crises: a cada mudança dominial, elabora-se novo calendário para marcar (justificando) o novo delegado do mandato ancestral.

$\mathrm{Na}$ difusão de poderes sobre a comunidade ${ }^{20}$, a escravidão - forma extrema da servidão - só poderia ser excepcional na China Antiga e, quando, raramente, adotada (geralmente prisioneiros estrangeiros), complementar à ampla variedade servil, no âmbito doméstico da nobreza e em obras imperiais (BUENO, 2002, p. 10 a 13).

\section{CIVILIZAÇÃO ROMANA}

Fundada (753 antes da Era Comum) por povos latinos subjugados por etruscos, no contexto de disputas bélicas (volscos, équos, sabinos, gauleses, samnitas e colonos gregos) pelo controle da península itálica, a cidade-estado de Roma era governada por reis, geralmente provenientes de famílias etruscas, as quais compunham uma aristocracia conjunta com famílias latinas pioneiras (patres) da ocupação territorial. Seus descendentes foram os patrícios, cujos anciões integravam um conselho real (Senado), onde não se admitiam imigrantes latinos que afluíram (plebe), progressivamente, amealhando a cidade em pequenas propriedades familiares. ${ }^{21}$ (ROSTOVTZEFF, 1983 capítulo I).

À cisão entre patrícios e plebeus correspondiam dois tipos de curiae (agrupamentos romanos com centro próprio de reuniões, representantes eleitos e ritos religiosos específicos): Patrícios se aglutinavam em subdivisões das três tribos

\footnotetext{
19 Conferir os capítulos onze, doze e treze A Civilização Chinesa (GRANET, 1979)

20 Conferir o capítulo vinte A Civilização Chinesa (GRANET, 1979)

21 Conferir o primeiro capítulo História de Roma (ROSTOVTZEFF, 1983)
} 
fundadoras, devotadas a Júpiter, Juno e Minerva; plebeus em ordens devotas de Ceres, Libera e Líber (p. 30, 41 e 42). Tais dádivas-partilha (MAUSS, 2003, p. 187) de caráter politico-religioso (inclusive divindades distintas), entre patrícios, de um lado, e plebeus, de outro, embora formulassem respectivas identidades coletivas, também correspondiam à sua divisão e oposição, no seio da população romana.

Destituindo o rei (508 antes da Era Comum), os patrícios findaram o domínio etrusco e inauguraram uma República, onde compunham as instituições principais (o Exército e o Senado) da política romana. As dinastias etruscas foram substituídas por dois mandatários temporários (cônsules), cuja ocupação (embora por eleição inclusiva da população plebeia) pelos nobres já amparados pelo Senado vitalício, institucionalizava uma dádiva agonística entre os patrícios na direção do Estado. $\mathrm{O}$ corpo eleitoral (Assembleia Popular) fora dividido em centuriae, que se sobrepunham às ordens plebeias e de modo que o peso dos votos plebeus era minoritário. Como apenas patrícios podiam ser eleitos cônsules, sua ocupação exprimia o prestigio adquirido pelos nobres, na sua disputa pelos votos de seus congêneres e dos plebeus (aos quais conferiam constantes prebendas). O caráter aristocrático era garantido ou acentuado pela clientela (plebeus agregados por famílias patrícias como prestadores de serviços) arregimentada - cuja magnitude expressava sua influência, inclusive sobre a plebe- nas eleições, onde votavam com seus patronos (ROSTOVTZEF, 1983, p. 31, 32 e 34).

A hegemonia patrícia da República, cujos cônsules geralmente seguiam os conselhos do Senado, foi vulnerada, porém, por duas tendências, que afetariam o sentido aristocrático da cidade-estado: a reorganização plebeia e a recomposição do Exército romano.

Ainda sob o contexto bélico no qual emergira, ameaçada por vários povos do entorno, Roma fora invadida (390 antes da Era Comum) por gauleses. Destruindo parte dela, além de saqueá-la e extorquir-lhe multas, a invasão gaulesa demostrou que o Exército aristocrático, restritivo do acesso plebeu, não podia defendê-la. Retomou-se um sistema outorgado, no passado, pelo rei Sérvio Túlio e que impunha o serviço militar a todos os romanos com terras na cidade - como a plebe de pequenos proprietários - mas acrescentando o acesso a terras pelos soldados, institucionalizando, paulatinamente, um costume pelo qual os patrícios premiavam os clientes que os seguiam nas batalhas (ROSTOVTZEF, 1983, pp. 36/37). 
A plebe romana continuou aperfeiçoando sua organização exclusiva, com dissidências (quando os plebeus se recusavam ao serviço militar), até que lhes franqueassem terras e pudessem ser eleitos cônsules (367 antes da Era Comum), tornando leis as decisões das assembleias plebeias (287 antes da Era Comum). Os tribunos - representantes eleitos dos plebeus, desde o século IV antes da Era Comum convocavam suas assembleias exclusivas, gozando de veto sobre outras decisões, inclusive dos cônsules (ROSTOVTZEF, 1983, pp. 34-42). A elite plebeia se imiscuía na direção do Estado, de modo que, sem deslocar a nobreza, integrava a aristocracia romana (ROSTOVTZEF, 1983, pp. 51-52).

Enquanto o Senado era constituído, costumeiramente, por quem exercera altas magistraturas, inclusive os cônsules, se tornando conselheiros vitalícios (ROSTOVTZEF, 1983, pp. 53-54), o Exército Cidadão coincidia com a Assembleia Popular, eletiva de todos os magistrados e cuja reunião, como o comando militar, era dos cônsules. Apesar de abertos à plebe, os cargos eletivos, frequentemente, foram ocupados por famílias nobres, as quais mediam seu prestigio pelos magistrados (não eram remunerados) familiares e, portanto, se empenhavam nas eleições, onde a distribuição de presentes era comum (ROSTOVTZEF, 1983, pp. 39 -41).

Neste sentido, era um sistema de dádiva agonística generalizada (entre cidadãos romanos), pelo qual o prestigio pessoal e familiar decorria do desempenho militar nas batalhas e das prebendas nas eleições. Em ambos os casos, ascendia-se na hierarquia social, respectivamente, acarretando o acesso às terras conquistadas por Roma ou às magistraturas romanas. A vantagem patrícia no sistema decorria de sua capacidade relativa superior de cumprir a incessante obrigação de conferir eficácia bélica (patrícios compareciam com mais equipamentos e seus clientes) e distribuir presentes eleitorais (mais a maior número de eleitores).

Transitar da dádiva agonística patrícia (comportada pela hegemonia senatorial) para uma dádiva agonística cidadã (inclusiva da plebe), implicou na ascensão do Exército como seu âmbito principal, à medida que conquistas militares se tornaram imprescindíveis, tanto para terras aos soldados (cidadãos), quanto às carreiras políticas ao consulado (Mario, Sila, Pompeu, Cesar) republicano. Por não suportá-la, a República cedeu ao Principado (em 17 antes da Era Comum), no qual o Exército continuou ampliando sua inserção, de mera base autocrática até à entronização de Imperadores militares (pós-Marco Aurélio). No século III da Era Comum, o Exército de cidadãos já 
predava o Império, asfixiado pelos impostos exigidos pela militarização, cujo ápice foi a hereditariedade militar (Adriano), no século II da Era Comum (MUSCO MENDES, 2005). Tornando-se exclusivamente militar, o sistema de dádivas agonísticas esgotou o Império e implodiu o Exército romano: incapaz de abandonar um ritmo expansionista, para além de seus efetivos cada vez mais insuficientes, adotou forças mercenárias que, gradativamente, não pôde manter sem franquear a própria Roma - o que, afinal, ocorreu em 476 da Era Comum, na tomada da cidade e deposição do Imperador Rômulo pelos hérulos (BARROS, 2009, p. 02).

Se o modo de exercício de dádivas agonísticas definiu a dinâmica romana antiga, então a intensidade da servidão foi fornecida pelo grau de competição no agon. Sua generalização (cidadã) no contexto romano implicaria uma intensificação maior do agon, à qual corresponderia equivalente incremento da servidão em geral, característico da trajetória romana, desde a constituição do Exército de cidadãos: dos conflitos com o Senado, à concentração (Sila, Pompeu, César) de poderes em um só cônsul, se seguiu o Princeps (Augusto), cuja evolução submeteu, crescentemente, as demais instituições romanas, até redundar nas rotativas entronizações militares, cumuladas na monarquia divina (Constantino).

Também o predomínio da escravidão, extrema servidão laboral, nesta civilização (GUARINELLO, 2006, p. 02 e 03), pode ser atribuído - como em Atenas e Esparta (GARLAN, 1982) - à expansão estrangeira adotada para suprimento constante (de mão de obra, como de outros bens) às competitivas dádivas (agonísticas) cidadãs. $\mathrm{Na}$ cidade, a dependência entre cidadãos agonísticos (patrícios e plebeus) se oporia à rivalidade de dádivas (as quais pressupõem a autonomia dos doadores), impedindo que a servidão de romanos se ampliasse - para além da excepcional clientela. A escravidão de devedores findou em 326 antes da Era Comum (MEIRA, 1971, p. 311) e só o definhamento imperial (BARROS, 2009, p. 04 e 05) propiciou a conversão de escravos em servos rurais, gerando os laços servis da emergente Europa medieval (BLOCH, 1990 , p. 80 a 84).

\section{CONCLUSÕES}

A abordagem integracionista - formulada por Marcel Mauss - da Antiguidade propicia salientar, neste período histórico, as institucionalidades das civilizações antigas 
Disponível em: www.revistafenix.pro.br

como veiculações refinadas do exercício de dádivas agonísticas nas e às suas populações. Contribui, especialmente, para compreender ou mesmo explicar suas trajetórias expansionistas e conflitos internos que, eventualmente, também as minaram, inclusive até seu declínio institucional: na intensificação exponencial da obrigação de suas elites doarem e retribuírem a suas populações se pode identificar tanto a superação (total ou parcial) de dádivas-partilha matriciais à coletividade, quanto o agon competitivo que as animou durante o exercício governamental.

Resultantes da sistematização de trocas competitivas entre dádivas cujo ideal normativo (com ou sem conotação jurídica) consiste em doações cuja retribuição seja penosa (senão impossível) e em retribuições exponencialmente superiores (ao recebido), pelos donatários, as quatro civilizações antigas - acima referidas - podem ser concebidas como sistemas de dádivas agonísticas específicas. Se todas normalizaram relações sociais servis, em geral, cada qual é um case no qual suas elites políticas competiam no exercício de dádivas, principalmente, divinas e militares entre templos e faraós egípcios, brâmanes e xatryas indianos; divinas, materiais e militares entre nobres chineses e seus antepassados; materiais e militares entre cidadãos romanos. Seu prestigio (e destino) político residia, diretamente, no desafio constante das e às dádivas que honrassem, ou seja, redistribuíssem às populações.

\section{REFERÊNCIAS BIBLIOGRÁFICAS}

AUBOYER, J. A vida cotidiana na Índia Antiga. Rio de Janeiro: Livros do Brasil. 2002. (1957)

ANEQUIN, Guy. A civilização Indiana. Rio de Janeiro: Editora Ferni. 1979.

AYMARD, André. A vida dos Zhou. In: Crouzet, M. (Org) História Geral das Civilizações. Difel: Lisboa, 1957.

BARROS, José D. Passagens da Antiguidade Romana ao Ocidente Medieval: leituras historiográficas de um período limítrofe. In: Revista História, vol.28, n.1, Franca, SP, 2009.

BUENO, André. Aspectos da escravidão na antiga China Han. In: Revista Helade, vol. 3. N. 2, 2002.

BLOCH, Marc. A sociedade feudal. Lisboa: edições 70, 1990.

CAILLÉ, Alain (1998) - Nem holismo nem individualismo metodológico: Marcel Mauss e o paradigma da dádiva. In: Revista brasileira de ciências sociais, vol. 13, n.38, SP.

CARDOSO, Ciro F. Trabalho compulsório na Antiguidade. Rio de Janeiro: Graal, 1987.

GARLAN, Yvon. Les esclaves en Gréce Ancienne. Paris: Maspero, 1982, Maspero. 
GOODY, Jack. O roubo da História. Rio de Janeiro: Contexto, - 2004.

GODBOUT, J.T. Introdução à dádiva. In: Revista Brasileira de Ciências Sociais, vol. 13,n 38, SP, 1998.

GUARINELLO, Norberto Luiz. Escravos sem senhores: escravidão, trabalho e poder no mundo romano. In: Revista brasileira de História, vol. 26, n. 52, SP, 2006.

GRANET, Marcel. A Civilização Chinesa. Rio de Janeiro: Otto Pierre, 1979 (1928).

MAUSS, Marcel. A Nação. São Paulo: Três Estrelas, 2017.

Ensaios de Sociologia. São Paulo: Perspectiva, 2015.

. Ensaio sobre a dádiva. In: Sociologia e Antropologia. São Paulo: Cosac \& Naify, 2003.

MEIRA, Silvio A. B. Instituições de Direito Romano. São Paulo:Max Limonad, 1971. MORET, Alexandre. L'Egypt Pharaonique. Paris: Plon, 1932.

MUSCO Mendes. Norma et alii. A experiência imperialista romana: teorias e práticas In: Revista Tempo, vol. 9, n. 18, Niterói, RJ, 2005.

ROSTOVTZEFF, M. História de Roma. Rio de Janeiro: Zahar, 1983.

WOLFE, Eric. Europe and the people without history. Berkeley: University of California Press, Berkeley, 1994. 